\title{
A highly efficient $\beta$-glucosidase from the buffalo rumen fungus Neocallimastix patriciarum W5
}

Hsin-Liang Chen ${ }^{1 \dagger}$, Yo-Chia Chen ${ }^{2 \dagger}$, Mei-Yeh Jade Lu ${ }^{1 \dagger}$, Jui-Jen Chang ${ }^{1,3+}$, Hiaow-Ting Christine Wang ${ }^{3}$, Huei-Mien Ke ${ }^{1,7}$, Tzi-Yuan Wang ${ }^{1}$, Sz-Kai Ruan ${ }^{1}$, Tao-Yuan Wang ${ }^{1}$, Kuo-Yen Hung ${ }^{3}$, Hsing-Yi Cho ${ }^{4,5,6}$, Wan-Ting Lin ${ }^{6}$, Ming-Che Shih ${ }^{4,6,8^{*}}$ and Wen-Hsiung Li $\mathrm{Li}^{1,3,8,9^{*}}$

\begin{abstract}
Background: Cellulose, which is the most abundant renewable biomass on earth, is a potential bio-resource of alternative energy. The hydrolysis of plant polysaccharides is catalyzed by microbial cellulases, including endo- $\beta$-1,4-glucanases, cellobiohydrolases, cellodextrinases, and $\beta$-glucosidases. Converting cellobiose by $\beta$-glucosidases is the key factor for reducing cellobiose inhibition and enhancing the efficiency of cellulolytic enzymes for cellulosic ethanol production.

Results: In this study, a cDNA encoding $\beta$-glucosidase was isolated from the buffalo rumen fungus Neocallimastix patriciarum W5 and is named NpaBGS. It has a length of 2,331 bp with an open reading frame coding for a protein of 776 amino acid residues, corresponding to a theoretical molecular mass of $85.1 \mathrm{kDa}$ and isoelectric point of 4.4. Two $\mathrm{GH} 3$ catalytic domains were found at the $\mathrm{N}$ and $\mathrm{C}$ terminals of NpaBGS by sequence analysis. The CDNA was expressed in Pichia pastoris and after protein purification, the enzyme displayed a specific activity of $34.5 \mathrm{U} / \mathrm{mg}$ against cellobiose as the substrate. Enzymatic assays showed that NpaBGS was active on short cello-oligosaccharides from various substrates. A weak activity in carboxymethyl cellulose (CMC) digestion indicated that the enzyme might also have the function of an endoglucanase. The optimal activity was detected at $40^{\circ} \mathrm{C}$ and $\mathrm{pH} 5 \sim 6$, showing that the enzyme prefers a weak acid condition. Moreover, its activity could be enhanced at $50^{\circ} \mathrm{C}$ by adding $\mathrm{Mg}^{2+} \mathrm{Or} \mathrm{Mn}^{2+}$ ions. Interestingly, in simultaneous saccharification and fermentation (SSF) experiments using Saccharomyces cerevisiae BY4741 or Kluyveromyces marxianus KY3 as the fermentation yeast, NpaBGS showed advantages in cell growth, glucose production, and ethanol production over the commercial enzyme Novo 188. Moreover, we showed that the KY3 strain engineered with the NpaNGS gene can utilize $2 \%$ dry napiergrass as the sole carbon source to produce $3.32 \mathrm{mg} / \mathrm{ml}$ ethanol when Celluclast $1.5 \mathrm{~L}$ was added to the SSF system.
\end{abstract}

Conclusion: Our characterizations of the novel $\beta$-glucosidase NpaBGS revealed that it has a preference of weak acidity for optimal yeast fermentation and an optimal temperature of $\sim 40^{\circ} \mathrm{C}$. Since NpaBGS performs better than Novo 188 under the living conditions of fermentation yeasts, it has the potential to be a suitable enzyme for SSF.

Keywords: Endoglucanase, $\beta$-glucosidase, Neocallimastix patriciarum, Rumen fungi, Simultaneous saccharification and fermentation

\footnotetext{
* Correspondence: mcshih@gate.sinica.edu.tw; whli@uchicago.edu

${ }^{\dagger}$ These authors contributed equally to this work.

${ }^{1}$ Biodiversity Research Center, Academia Sinica, Taipei 115, Taiwan

${ }^{3}$ Genomics Research Center, Academia Sinica, Taipei 115, Taiwan

Full list of author information is available at the end of the article
} 


\section{Background}

Cellulose is the major component in the plant cell wall. It is a linear polymer of polysaccharide consisting of $\mathrm{D}$-glucose units linked by 1,4- $\beta$-D-glucosidic bonds. The hydrolysis of plant polysaccharides is catalyzed by microbial cellulases, including endo- $\beta$-1,4-glucanases, cellobiohydrolases, cellodextrinases and $\beta$-glucosidases [1]. These cellulases are very important in various applications, including saccharification of industrial and agricultural cellulose containing residues, treating cellulose pulp wastes in the paper industry and enhancing the extraction of fermentable substances in the beer brewing and alcohol fermentation industries [2-4]. In the process of cellulose degradation, various endo$\beta$-1,4-glucanases act randomly along the cellulose chains, producing cellulose fragments to generate new sites on which cellodextrinases act to produce cellobiose or oligosaccharides. $\beta$-glucosidases then catalyze the hydrolysis of cellobiose and oligosaccharides, which are strong inhibitors of both endo- $\beta$-1,4-glucanases and cellodextrinases [5-7]. Thus, converting cellobiose or oligosaccharides to glucose is the key factor for reducing cellobiose inhibition and enhancing the efficient of cellulolytic enzymes $[5,8,9]$.

According to the classification by $[10,11], \beta$-glucosidase genes are typically placed into glycosyl hydrolase families 1 and 3 (GH1 and GH3). Generally, the $\beta$-glucosidases of bacterial, plant, and mammalian origins that belong to GH1 usually possess a significant level of galactosidase activity in addition to $\beta$-glucosidase activity. The other $\beta$-glucosidases of fungi, bacteria, and plants are often classified into GH3. The $\beta$-glucosidases in both families are known as retaining enzymes because their products retain the same anomeric configuration as the substrate [12]. Their reactions are thought to follow a double-displacement mechanism [12].

Cellulolytic enzymes from brown- and white-rot fungi have been extensively studied in organisms such as Trichoderma reesei and Phanerochaete chrysosporium [13-16]. It is also known that rumen fungi are able to degrade the most resistant plant cell-wall polymers and therefore are rich sources of fibrolytic enzymes with tremendous potential for industrial and agricultural applications [16-18]. Recently, we reported the transcriptomic and secretomic profiles of the rumen fungus Neocallimastix patriciarum W5 [19]. From the transcriptome, we cloned and expressed a cDNA encoding a $\beta$-glucosidase. We call this enzyme NpaBGS and have pursued a detailed characterization in the present study. The protein sequence contains two GH3 domains at the $\mathrm{N}$ and $\mathrm{C}$ terminals from a domain prediction analysis. In a heterologous expression system, the purified $\beta$-glucosidase showed the optimal activity at $\mathrm{pH} 6$ and $40^{\circ} \mathrm{C}$ and could be significantly enhanced at $50^{\circ} \mathrm{C}$ by adding $\mathrm{Mg}^{2+}$ or $\mathrm{Mn}^{2+}$ ions. Furthermore, two fermentation yeasts were chosen to assess the potential of NpaBGS for the SSF process.

\section{Results and discussion}

\section{Characterization of the $\beta$-glucosidase NpaBGS}

The cloned NpaBGS cDNA contains 2,331 bp and the deduced amino acid sequence has 776 amino acid residues, with a theoretical molecular mass of $85.1 \mathrm{kDa}$ and isoelectric point of 4.4 (Additional file 1). The cleavage site for the putative signal peptide is located between residues Ala20 and Ile21. Three potential $N$-glycosylation sites were predicted at residues 51, 223 and 532. Conserved domain prediction suggests that it is a $\beta$-glucosidase of the glycosyl hydrolase Family 3 (GH3) carrying a GH3 N-terminal domain (Pfam00933) and a GH3 C-terminal domain (Pfam01915) located at residues $62 \sim 270$ and 350 577, respectively.

Based on amino acid sequences, glucosidases have been classified into several families, with most of the $\beta$-glucosidases belonging to either $G H 1$ or $G H 3[10,11,20]$. Comparative analyses using BlastX and ExPASy indicated that NpaBGS contains two conserved putative domains of GH3. The aspartic acid residue Asp251 in the conserved domain (GXVMXD) might be the active-site residue of NpaBGS [21-23].

\section{Purification of NpaBGS expressed in Pichia pastoris}

The expression of the NpaBGS cDNA in $P$. pastoris GS115 was conducted under the control of the inducible promoter AOX1 on the pPICZ A vector. A 2-day culture in a medium containing $0.5 \%$ methanol resulted in optimal enzyme production. These conditions were used in subsequent large scale cultures for enzyme purification and the results are summarized in Table 1. The pattern of fractions containing NpaBGS activities at each purification step was checked by SDS-PAGE (Figure 1A). A significant mass of the purified enzyme was estimated to be $85 \mathrm{kDa}$ by SDS-PAGE analysis. The enzyme was

Table 1 Summary of stepwise purification of NpaBGS ( $\beta$-glucosidase)

\begin{tabular}{|c|c|c|c|c|c|}
\hline $\begin{array}{l}\text { Purification } \\
\text { steps }\end{array}$ & $\begin{array}{l}\text { Total } \\
\text { activity } \\
\text { (U) }\end{array}$ & $\begin{array}{l}\text { Total } \\
\text { protein } \\
\text { (mg) }\end{array}$ & $\begin{array}{l}\text { Specific } \\
\text { activity } \\
(U / m g)\end{array}$ & $\begin{array}{l}\text { Purification } \\
\text { (fold) }\end{array}$ & $\begin{array}{l}\text { Recover } \\
\text { rate } \\
(\%)\end{array}$ \\
\hline Supernatant & 2396 & 198 & 12.1 & 1 & 100 \\
\hline Condensation & 1900 & 96 & 19.8 & 1.6 & 79 \\
\hline $\begin{array}{l}\text { Ammonium } \\
\text { sulfate precipitation }\end{array}$ & 985 & 47 & 21.0 & 1.7 & 41 \\
\hline $\begin{array}{l}1^{\text {st }} \text { DEAE-Sepharose } \\
\text { chromatography }\end{array}$ & 524 & 30 & 17.5 & 1.5 & 22 \\
\hline $\begin{array}{c}2^{\text {nd }} \text { DEAE-Sepharose } \\
\text { chromatography }\end{array}$ & 345 & 10 & 34.5 & 2.9 & 14 \\
\hline
\end{tabular}

The assay was conducted at $40^{\circ} \mathrm{C}, \mathrm{pH} 6$ for $1 \mathrm{hr}$. One unit enzyme activity was defined as 1 nmole of glucose released per minute. 


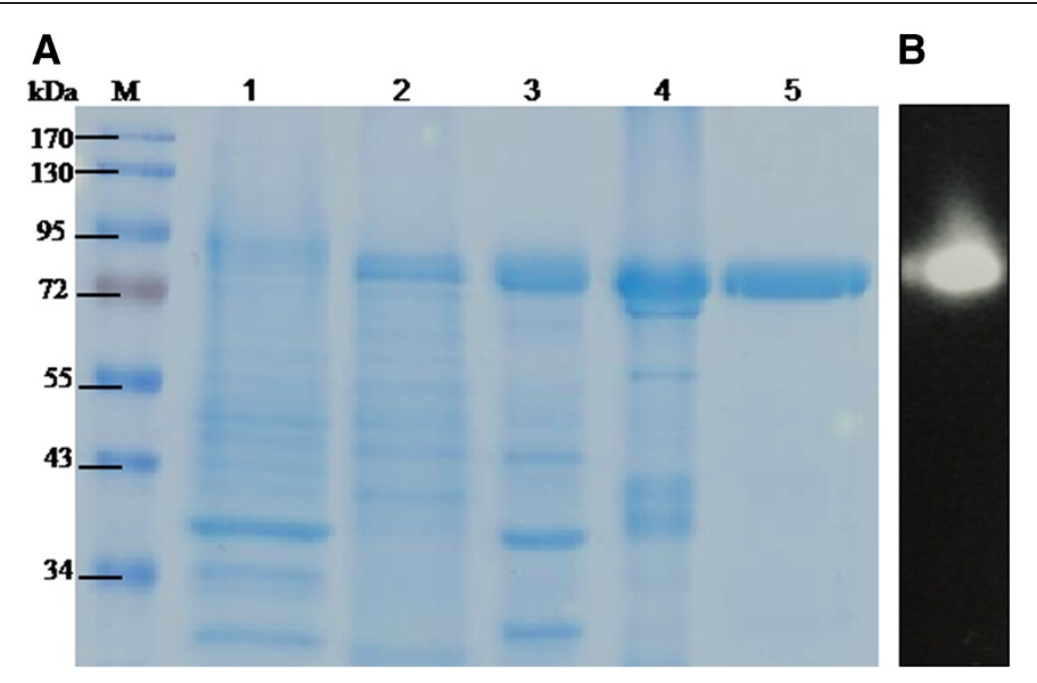

Figure 1 SDS-PAGE and Zymogram of NpaBGS, which was expressed and purified from a Pichia pastoris recombinant strain. (A) SDS-PAGE of NpaBGS after each purification step. Lane M, protein marker; lane 1, crude extract; lane 2, condensation; lane 3, ammonium sulfate precipitation; lane 4, $1^{\text {st }}$ DEAE; lane $5,2^{\text {nd }}$ DEAE. (B) Zymogram of the purified $\beta$-glucosidase in the native PAGE with MUC substrate staining.

purified 2.9-fold with a specific activity of $34.5 \mathrm{U} / \mathrm{mg}$ against cellobiose as the substrate. In addition, the $\beta$-glucosidase activity of the purified NpaBGS was examined by the zymogram assay with 4-methylumbelliferyl- $\beta$-Dcellobioside (MUC) staining after electrophoresis on the native PAGE (Figure 1B).

The evidence from enzymatic assay, bioinformatics and homology modeling studies also strongly suggest that NpaBGS is a member of GH3. In NpaBGS, three putative $\mathrm{N}$-glycosylation sites were found (Additional file 1), but no significant difference was observed between the calculated and the apparent molecular weight on SDS-PAGE using the Pichia expression system (Figure 1). Unlike reported cases of glycosylated $\beta$-glycosidases [12,24], there might be no or little glycosylation on NpaBGS. Furthermore, NpaBGS has also been successfully expressed in Escherichia coli, Bacillus subtilis, Kluyveromyces marxianus and K. lactis (data not shown). The enzyme with no or little glycosylation would be easier to express in both eukaryotic and prokaryotic systems, except for species such as $S$. cerevisiae that have a strong glycosylation mechanism. It will be interesting to do site-directed mutagenesis to study whether any of the three sites are actually glycosylated.

The purified NpaBGS and commercial enzyme Novo 188 were used to evaluate the effects of $\mathrm{pH}$ and temperature on enzymatic activity using cellobiose as the substrate. The maximum activities of NpaBGS and Novo 188 were observed at $40^{\circ} \mathrm{C}$ and $60^{\circ} \mathrm{C}$, respectively, and NpaNGS was found to display a higher activity than Novo 188 at $40^{\circ} \mathrm{C}$, though a lower activity at $60^{\circ} \mathrm{C}$ (Figure $2 \mathrm{~A}$ ). Both enzymes showed about $80 \%$ residual activity at $50^{\circ} \mathrm{C}$. At $\mathrm{pH}$ 6.0, NpaBGS showed a relative activity of $58 \%$ at $30^{\circ} \mathrm{C}$ and $86 \%$ at $50^{\circ} \mathrm{C}$. The effect of $\mathrm{pH}$ on the hydrolysis rate was also evaluated for NpaBGS in a reaction system incubated at $40^{\circ} \mathrm{C}$ for $1 \mathrm{~h}$. High levels of NpaBGS activity were found in a narrow $\mathrm{pH}$ range (5.0-6.0), peaking at $\mathrm{pH}$ 6.0 (Figure 2B). At $\mathrm{pH}$ values outside the range of 5.0 to 8.0, the relative activities decreased significantly. In contrast, Novo 188 showed an acidity-tolerance at $\mathrm{pH} 4$. The activities of NpaBGS under conditions at different $\mathrm{pH}$ values and temperature indicated that NpaBGS prefers weak acidity as the yeast fermentation condition.

\section{Substrate specificity of NpaBGS}

The NpaBGS substrate specificity was determined using the purified protein to avoid the background $\beta$-glucosidase activity of $P$. pastoris. All substrates were assayed at $40^{\circ} \mathrm{C}$ and $\mathrm{pH} 6$ for $1 \mathrm{~h}$. As shown in Table 2, enzyme activities were detected for natural substrates such as amygdalin, arbutin, larminarin, phenyl- $\beta$-D-glucoside, $\beta$-gentiobiose as well as cellobiose. It showed little or no activity for other sugars such as sinigrin, maltose, lactose and sucrose. For synthetic substrates, MUC and MUD were found to have the best activity, but no activity was detectable for MUG (data not shown). Moreover, when MUC was used, the enzymatic product generated measurable fluorescence, indicating that this enzyme was active on short cellooligosaccharides (Figure 1B).

Most $\beta$-glucosidases can be divided into three groups with respect to their substrate specificity: (a) those that exhibit a high specificity towards aryl $\beta$-D-glucosides, (b) those that preferentially hydrolyze cellobiose and cello-oligosaccharides (also known as cellobiases), and (c) those that hydrolyze both types of substrates (i.e., broad-specificity $\beta$-glucosidases) [24]. From our experiments, NpaBGS displayed a higher activity on 4-methylumbelliferyl 


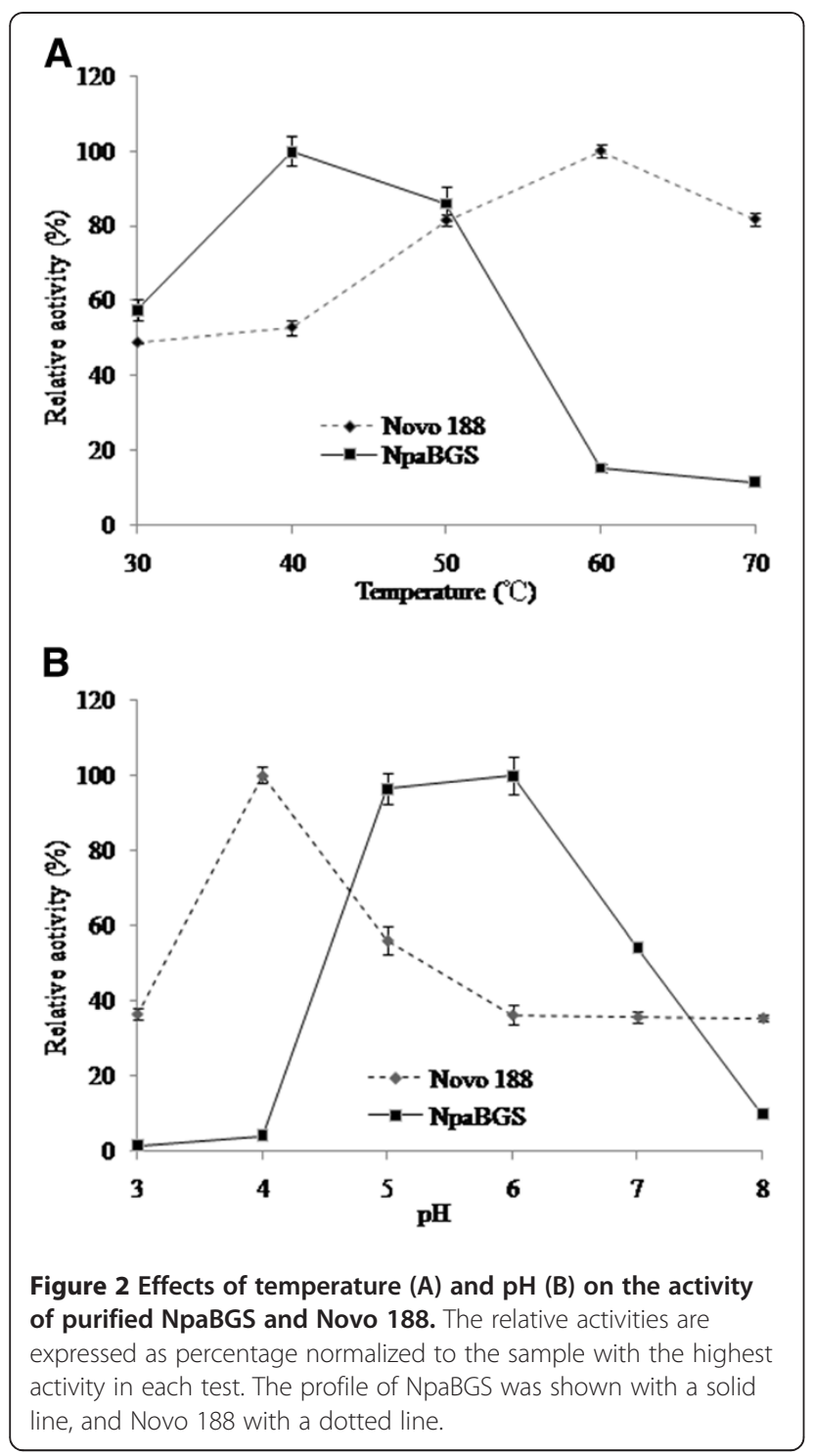

substrates than on cellobiose, demonstrating that NpaBGS has a very high affinity for methylumbelliferyl substrates (Table 2). In addition, NpaBGS hydrolyses CMC (Additional file 2) and MUC (Table 2), suggesting that the enzyme possesses both endo-glucanase and $\beta$-glucosidase activities [25-28]. Thus, this enzyme showed a strong $\beta$ glucosidase activity and might also possess other cellulase functions.

Effects of different elements on the NpaBGS activity

To study the effects of metal ions and reducing agents on the NpaBGS activity, we conducted assays in the presence of metal cations, including $\mathrm{Al}^{3+}, \mathrm{Ca}^{2+}, \mathrm{Cu}^{2+}$, $\mathrm{Fe}^{3+}, \mathrm{Mg}^{2+}, \mathrm{Mn}^{2+}$ and $\mathrm{Zn}^{2+}$, and reducing agents, such as DTT and $\beta$-mercaptoenthanol, at the concentrations of 1 and $10 \mathrm{mM}$ (Table 3). At the concentration of $1 \mathrm{mM}$, only $\mathrm{Mg}^{2+}, \mathrm{Mn}^{2+}$ and $\mathrm{Zn}^{2+}$ showed significant
Table 2 Substrate specificity of purified NpaBGS

\begin{tabular}{cc}
\hline Substrate & Relative activity (\%) \\
\hline Amygdalin & 92 \\
Sinigrin & 1 \\
Esculin & 87 \\
Phenyl- $\beta$-D-glucoside & 99 \\
Arbutin & 95 \\
$\beta$-methyl-D-glucoside & 11 \\
Cellobiose & 100 \\
$\beta$-Gentiobiose & 93 \\
Maltose & 0 \\
Lactose & 0 \\
Sucrose & 0 \\
Laminarin & 98 \\
4-methylumbelliferyl- $\beta$-D-cellobioside & 265 \\
4-methylumbelliferyl- $\beta$-D-glucopyranoside & 255 \\
\hline -mblumbelliferyl- $\beta$-D- galactopyronoside & 0
\end{tabular}

The assay was performed at $40^{\circ} \mathrm{C}, \mathrm{pH} 6$ for $1 \mathrm{hr}$ using 0.01 units $/ \mathrm{ml} \mathrm{NpaBGS}$ enzyme. The relative activities are expressed as percentage by normalizing to the cellobiose reaction activity.

enhancement of $\beta$-glucosidase activity compared to the reaction containing the chealator EDTA. When the concentration was increased to $10 \mathrm{mM}, \mathrm{Al}^{3+}, \mathrm{Cu}^{2+}$ and $\mathrm{Fe}^{2+}$ all showed significant inhibition of enzymatic activity; $\mathrm{Al}^{3+}$ and $\mathrm{Cu}^{2+}$ almost abolished the function. In contrast, $\mathrm{Ca}^{2+}, \mathrm{Mg}^{2+}, \mathrm{Mn}^{2+}$ and $\mathrm{Zn}^{2+}$ showed significant enhancement of $\beta$-glucosidase activity, especially for $\mathrm{Mg}^{2+}$ and $\mathrm{Mn}^{2+}$, which showed very strong enhancement (Table 3). Supplementing either DTT or $\beta$-mercaptoenthanol showed no apparent effects on enzymatic activity under the condition tested.

Table 3 Effect of metal ions and reducing agents on the activity of purified NpaBGS

\begin{tabular}{ccc}
\hline Metal & $\mathbf{1 ~} \mathbf{~} \mathbf{M}$ & $\mathbf{1 0 ~} \mathbf{~ M}$ \\
\hline $\mathrm{AlCl}_{3} \cdot 6 \mathrm{H}_{2} \mathrm{O}$ & 104 & 7 \\
$\mathrm{MgSO}_{4} \cdot 7 \mathrm{H}_{2} \mathrm{O}$ & 132 & 152 \\
$\mathrm{CaCl}_{2} \cdot 2 \mathrm{H}_{2} \mathrm{O}$ & 109 & 136 \\
$\mathrm{MgCl}_{2} \cdot 6 \mathrm{H}_{2} \mathrm{O}$ & 132 & 150 \\
$\mathrm{MnCl}_{2} \cdot 2 \mathrm{H}_{2} \mathrm{O}$ & 142 & 151 \\
$\mathrm{ZnCl}_{2}$ & 116 & 133 \\
$\mathrm{CuCl}_{2} \cdot 2 \mathrm{H}_{2} \mathrm{O}$ & 97 & 3 \\
$\mathrm{FeCl}_{3} \cdot 2 \mathrm{H}_{2} \mathrm{O}$ & 95 & 37 \\
$\beta$-mercaptoenthanol & 104 & 105 \\
Dithiothreitol & 103 & 101 \\
EDTA & 100 & 91
\end{tabular}

The assay was performed at $40^{\circ} \mathrm{C}, \mathrm{pH} 6$ for $1 \mathrm{hr}$ using $0.01 \mathrm{units} / \mathrm{ml}$ of the NpaBGS enzyme. The relative activities are expressed as percentage by normalizing to the control activity. 
We examined whether $\mathrm{Mg}^{2+}$ and $\mathrm{Mn}^{2+}$ could enhance $\mathrm{pH}$ or temperature tolerance of NpaBGS. We found no effect of these ions on $\mathrm{pH}$ tolerance (data not shown), but addition of either cation increased NpaBGS's activity at higher temperatures (Figure 3). Interestingly, significant enhancement of the activity by the supplement of $\mathrm{Mn}^{2+}$ was found at $50^{\circ} \mathrm{C}$ over those assayed at $40^{\circ} \mathrm{C}$, suggesting the potential of in vitro application in digesting cellulose at elevated temperatures by supplementing enhancing cations.

According to previous studies, supplementing divalent or trivalent cations is one strategy to increase enzyme reaction efficiency, thermostability or termination reaction. Different levels of inhibitory effect on enzyme activities by metal ions have been reported, especially $\mathrm{Cu}^{2+}$ and $\mathrm{Fe}^{2+}$ for $\beta$-glucosidase [24,29-31]. In a previous study, $\mathrm{Ca}^{2+}$ showed several benefits including protein conformation stabilization, higher affinity for the substrate, and a higher thermostability of an endoglucanase of Clostridium thermocellum [32]. However, $\mathrm{Mg}^{2+}$ and especially $\mathrm{Mn}^{2+}$ showed a stronger enhancement than $\mathrm{Ca}^{2+}$ on the $\beta$-glucosidase activity of NpaBGS (Table 3 \& Figure 3 ). In our tests, $\mathrm{Al}^{3+}, \mathrm{Cu}^{2+}$ and $\mathrm{Fe}^{3+}$ showed a significant inhibition of NpaBGS activity at $10 \mathrm{mM}$ (Table 3). This indicated that the requirement of free sulfhydryl groups in NpaBGS is similar to those observed in other $\beta$-glucosidases [33]. The sequence data also suggested that there are thiol groups presented at the active site that are involved in binding or catalysis, or that such groups are essential for maintaining a proper tertiary structure of the enzyme [34-36]. This is consistent with the suggestion that the cysteine residue is involved in the stability and activity of $\beta$-glucosidases [37]. On the other hand, we found the stimulatory effect of ions on NpaBGS (Table 3) as reported in other studies [28,38]. This stimulation has been regarded as promoting a

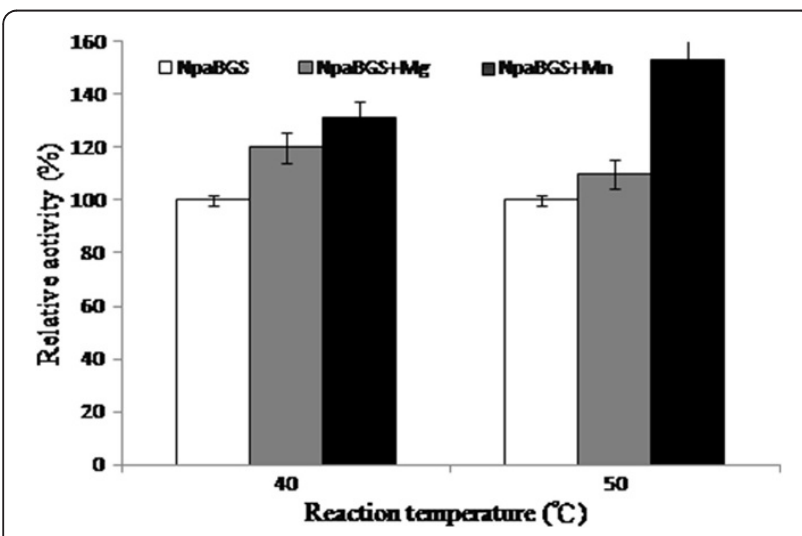

Figure 3 The effects of $\mathrm{Mg}^{2+}$ and $\mathrm{Mn}^{2+}$ cations, to a final concentration of 1 and $10 \mathrm{mM}$, on the activity of purified NpaBGS at $\mathrm{pH}$ 6.0. The activity of NpaBGS (open square), NpaBGS with $\mathrm{Mg}^{2+}$ (gray square) and $\mathrm{NpaBGS}$ with $\mathrm{Mn}^{2+}$ (black square) were compared. significant reduction in the binding specificity and/or deactivation of the site [39].

\section{Performance of NpaBGS in Simultaneous Saccharification and Fermentation}

Since cellobiose digestion by $\beta$-glucosidase might be affected by the end-product feedback inhibition, it is not easy to compare the hydrolytic efficiencies of NpaBGS and Novo 188 (data not shown). We therefore employed a SSF process to compare the efficiencies of NpaBGS and Novo 188. We added an equal amount (2 units) of NpaBGS or Novo 188 separately to $10 \mathrm{ml}$ of yeast cultures with $2 \%$ cellobiose as the sole carbon source and compared their effects on yeast growth. The brewers' yeast Saccharomyces cerevisiae BY4741 and the thermostable kefir yeast $K$. marxianus KY3 [40] were employed in separate experiments. Both cultures showed a better growth profile in cell density with the addition of purified NpaBGS than with the addition of Novo 188 at $30^{\circ} \mathrm{C}$ (Figure 4A). K. marxianus $\mathrm{KY} 3$ was also studied at higher temperatures, i.e., $37^{\circ} \mathrm{C}$ and $40^{\circ} \mathrm{C}$. It grew better at $37^{\circ} \mathrm{C}$ than at $40^{\circ} \mathrm{C}$ or $30^{\circ} \mathrm{C}$ (Figure $4 \mathrm{~A}$ ).

The effects of NpaNGS and Novo 188 on ethanol fermentation in SSF at different temperatures were also studied. When the yeasts were inoculated in $\mathrm{SSF}$ at $30^{\circ} \mathrm{C}$, the yeast cultured with NpaBGS showed a better performance in ethanol conversion than the yeast cultured with Novo 188; the same results were observed for both yeast hosts KY3 and S. cerevisiae (Figure 4B). In addition, because $40^{\circ}$ $\mathrm{C}$ is the optimal condition for ethanol production by $K$. marxianus KY3 [40] and for the enzyme reaction of NpaBGS (Figure 2), a higher ethanol productivity was observed at $40^{\circ} \mathrm{C}$ than at $37^{\circ} \mathrm{C}$ and $30^{\circ} \mathrm{C}$ (Figure $4 \mathrm{~B}$ ). Although the yeasts stopped producing ethanol after $12 \mathrm{~h}$ of culturing, more than $50 \%$ cellobiose was converted to ethanol by $K$. marxianus $\mathrm{KY} 3$ in the SSF process at $37^{\circ} \mathrm{C}$ and $40^{\circ} \mathrm{C}$. The efficiency of cellobiose digestion by either NpaBGS or Novo 188 was significantly lowered after 12 hours of reaction (data not shown), but the digested sugar was still sufficient to support a weak growth of the yeasts (Figure 4A). These data indicated that removing the feedback inhibitor (glucose) by yeasts could enhance the activity of $\beta$-glucosidase, as reflected by the ethanol productivity by both S. cerevisiae BY4741 and K. marxianus KY3. Note that the ethanol production rate at $40^{\circ} \mathrm{C}$ and the growth rate at $37^{\circ} \mathrm{C}$ of $K$. marxianus $\mathrm{KY} 3$ with $2 \%$ cellobiose by the NpaBGS treatment was done using $2 \%$ glucose as the sole carbon source (data not shown). These SSF results indicated that NpaBGS had a significantly higher efficiency for SSF ethanol production by both yeast hosts than Novo 188 at all the temperatures tested, probably due to the faster cellobiose-digestion rate of NpaBGS than Novo 188 under the temperatures tested $\left(30-40^{\circ} \mathrm{C}\right)$. In summary, our data indicates that purified NpaBGS is active under a wide 

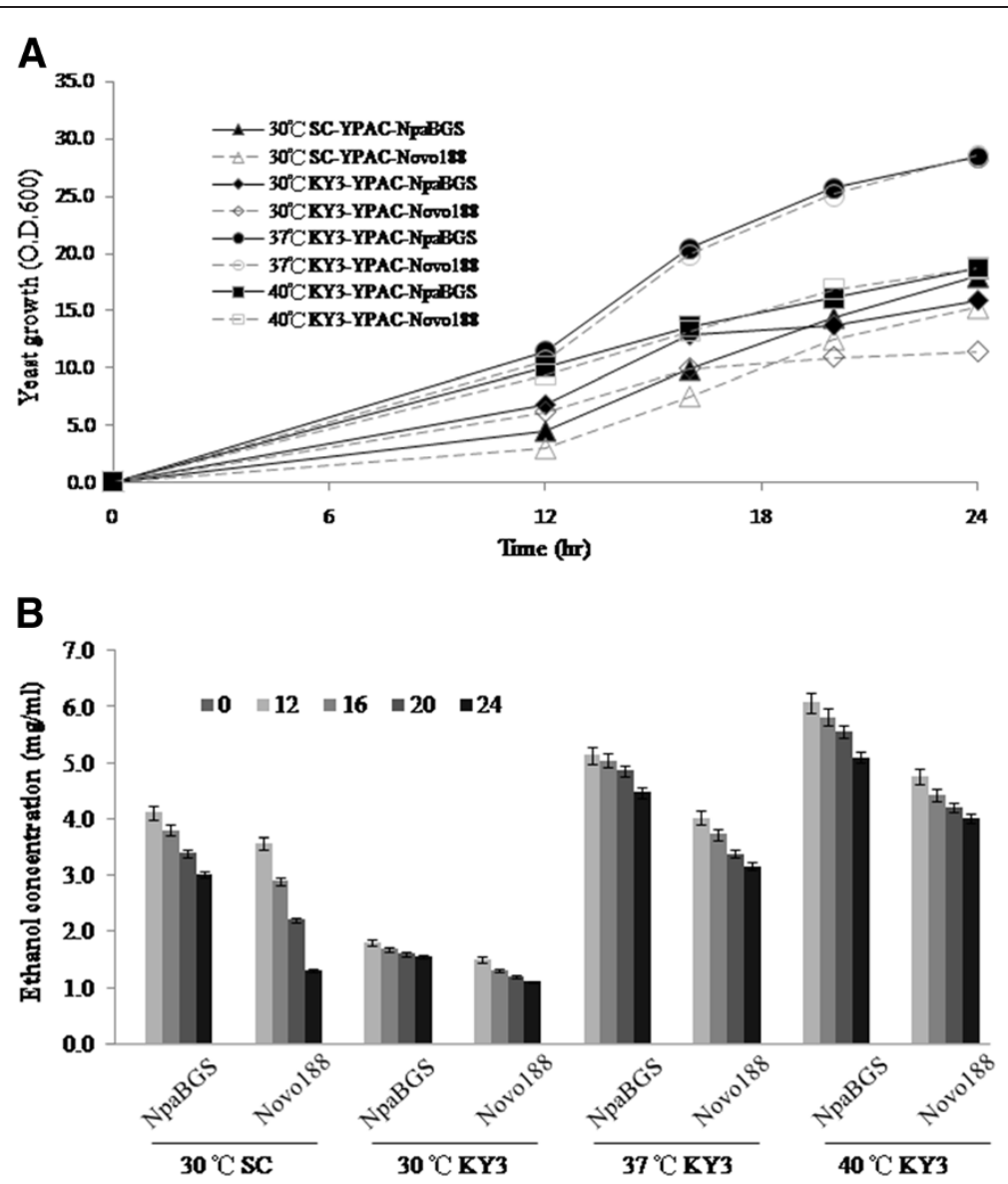

Figure 4 The performances of NpaBGS and Novo 188 in SSF at different temperatures. Equal units (2 units) of the two enzymes were added separately to $10 \mathrm{ml}$ yeast cultures with $2 \%$ cellobiose as the sole carbon source and their effects on yeast growth were compared. (A) The cell density assay of growth curve. (B) The ethanol productivity of SSF. SC: S. cerevisiae BY4741; KY3: K. marxianus KY3.

range of conditions, with the maximum activity at $40^{\circ} \mathrm{C}$ in the weak acid condition (pH 5.0-6.0). Moreover, with 1 unit of enzyme, NpaBGS showed a good efficiency in completely converting $2 \%$ cellobiose to glucose within 4 hours in the optimal buffer system (Figure 5). The time course assay with the two enzymes for cellobiose digestion was also examined at $40^{\circ} \mathrm{C}$ and $\mathrm{pH} 6.0$, and the data indicated that NpaBGS had a slightly better efficiency than Novo 188.

\section{Cellulosic ethanol conversion from napiergrass}

In the current process of SSF, the commercial Celluclast $1.5 \mathrm{~L}$ is usually employed for converting cellulose to cellobiose or oligosaccharides. Although Celluclast $1.5 \mathrm{~L}$ has high exo- and endo-glucanase activities, it has a very low $\beta$-glucosidase activity. Therefore, it is necessary to add a $\beta$-glucosidase, such as Novo 188 , to convert cellobiose to glucose. Instead of adding $\beta$-glucosidase, one may transform a $\beta$-glucosidase gene into the host. For this purpose, we succeeded in expressing the NpaBGS gene in $K$. marxianus $\mathrm{KY} 3$, and the new strain was employed

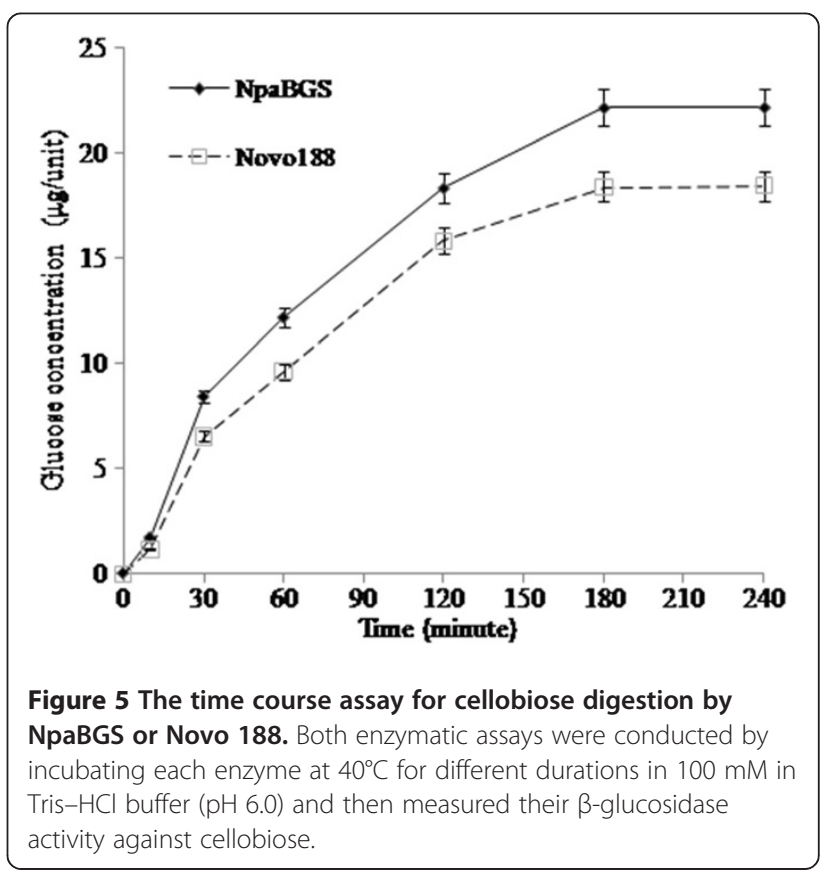


in SSF using dry napiergrass $(2 \%)$ as the feeding stock. While the wild-type KY3 alone could not produce any detectable amount of ethanol, the engineered strain KY3-NpaBGS could produce $1.09 \mathrm{mg} / \mathrm{ml}$ ethanol, probably by using the oligosaccharides of napiergrass, such as cellobiose and cellodextrin (Figure 6). Furthermore, as a SSF experiment we added $2 \mathrm{ml}$ of Celluclast $1.5 \mathrm{~L}$ to $50 \mathrm{ml}$ yeast cultures and compared their effects on KY3 and KY3-NpaBGS alcoholic fermentation. Again, KY3 produced no detectable amount of ethanol, while the strain KY3-NpaBGS could produce $3.32 \mathrm{mg} / \mathrm{ml}$ ethanol from napiergrass in one day aerobic culturing at $40^{\circ} \mathrm{C}$ (Figure 6). Although the efficiency of ethanol conversion was low, as a proof of concept the experiment showed that the NpaBGS gene has a potential to be applied in SSF or even in CBP if we also introduce both exo- and endo-glucanase genes into the host. The efficiency of ethanol production of SSF can be improved by using an anaerobic system, increasing the copy number of the NpaGNS genes and immobilizing the enzymes on the cell surface.

For practical applications such as the separate hydrolysis and fermentation (SHF) process, most of the commercial cellulases show a higher efficiency and thermostability at temperatures higher than $40^{\circ} \mathrm{C}$ [41]. In bio-fuel industry, SSF and simultaneous saccharification and co-fermentation (SSCF) are the two major processes currently used for cellulosic-ethanol production. However, most efficient microbes for ethanol production such as brewer's yeast live below $40^{\circ} \mathrm{C}$. For highly efficient SSF or SSCF, the enzymes should have a large capacity to digest the substrates in

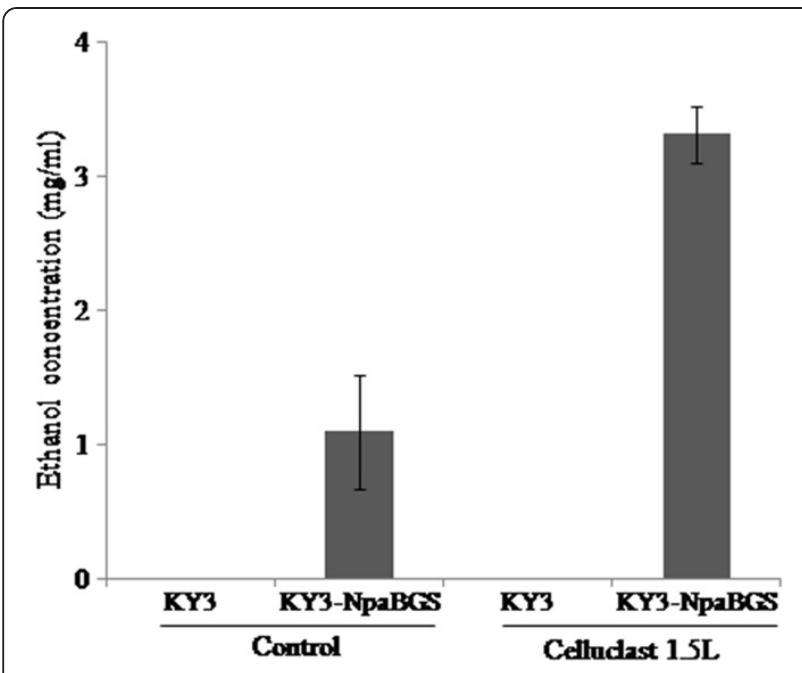

Figure 6 The ethanol productivity of the SSF experiment using $2 \%$ dry napiergrass as the solo carbon source. A $2 \mathrm{ml}$ of Celluclast $1.5 \mathrm{~L}$ was added to $50 \mathrm{ml}$ yeast cultures and two different strains, KY3 and KY3-NpaBGS, were inoculated in one day aerobic culturing at $40^{\circ} \mathrm{C}$. order to provide carbon sources for the microbes to grow under the same culture condition. A previously characterized rumen cellulase showed an optimal activity at $\mathrm{pH}$ from 4.0 to 7.0 and temperature from $35^{\circ} \mathrm{C}$ to $50^{\circ} \mathrm{C}$ [18]. In our experiments, two alcoholic fermentation yeasts were chosen to study the performances of NpaBGS and Novo 188 in SSF at different temperatures. Cell density, glucose concentration and ethanol concentration were used to evaluate the SSF efficiency. Although Novo 188 showed better digestion efficiency and thermostability than NpaBGS at higher temperatures (Figure 2), NpaBGS appeared to be superior to Novo 188 at $40^{\circ} \mathrm{C}$. Since $40^{\circ} \mathrm{C}$ is almost the highest temperature for microbe growth and fermentation, NpaBGS has a potential for a direct application in a bio-reactor system and for CBP.

Although the SSF concept has already been published in many previous studies, most of these studies focused on the enzyme cocktail and the enzyme/substrate blending proportion. Indeed, the related enzyme technology focused on enhancing the thermo-stability or increasing the acid tolerance of the cellulolytic enzymes. In this study, we isolated a new beta-glucosidase and showed that it has advantages over the commercial enzyme Novo 188 in SFF applications and that it can be transformed into a host to replace the use of Novo 188. Since NpaBGS was isolated from one of the best nature SSF system, the buffalo rumen, which undergoes microbial fermentation in $38^{\circ} \mathrm{C}$, it may have an advantage for constructing an artificial SSF system for yeast ethanol production. We considered a friendly environment for both host growth and the enzyme reaction. This new concept has the potential to reduce the cost as it requires no external supply of beta-glucosidase and it might improve the efficiency of a bio-process, such as SSF or CBP.

\section{Conclusions}

We have successfully cloned and expressed an extracellular $\beta$-glucosidase from $N$. patriciarum W5 and investigated its enzymatic properties. The optimal activity was detected at $40^{\circ} \mathrm{C}$ and pH 5-6, showing that the enzyme prefers a weak acid condition. Moreover, its activity at $50^{\circ} \mathrm{C}$ could be enhanced by adding $\mathrm{Mg}^{2+}$ or $\mathrm{Mn}^{2+}$ ions. The enzyme, NpaBGS, showed advantages in cell growth, glucose production, and ethanol production over the commercial enzyme Novo 188 in SSF. In addition, it was also employed with Celluclast $1.5 \mathrm{~L}$ to conduct an SSF experiment using dry napiergrass as the sole carbon source. The work presented here is the first study that considers an environment that is friendly for both host growth and the enzyme reaction. This new concept can help to improve the efficiency of bio-process, such as SSF and CBP, and it marks a notion to reassess what has missed in the old industry. Although many different fungal $\beta$-glucosidases have been identified and cloned, only a few were derived from rumen 
fungi. In this study, a novel $\beta$-glucosidase, NpaBGS, was isolated from buffalo rumen, which is one of the best natural SSF systems for microorganism fermentation at $38^{\circ} \mathrm{C}$, and it is shown to have a good potential for an artificial SSF system for ethanol production. .

\section{Methods}

\section{Cloning of NpaBGS cDNA}

The cDNA of NpaBGS was amplified by PCR using the Platinum Taq DNA Polymerase High Fidelity (Invitrogen, Carlsbad, CA, USA) with the gene-specific primers flanked by restriction site sequences, EcoRI/F1-1 (AATT CATGAAGTTCTCATCTGTTTTATCTACTG), EcoRI/ F1-2 (CATGAAGTTCTCATCTGTTTTATCTACTG), Xhol/ R1-1 (GTTAGTAAAGTTTGTAAGCTCTCTTC), Xhol/ R1-2 (TCGAGTTAGTAAA GTT TGTAAGCTCTCTTC), and PCR products were cloned into the pGEM-T vector (Promega Corp. Madison, WI, USA). The plasmid DNA from a positive clone was digested with XhoI and EcoRI and subcloned in frame with the $P$. pastoris pPICZ A expression vector. After sequencing confirmation of the NpaBGS cDNA, the recombinant plasmid, pPA-NpaBGS, was used to transform the P. pastoris GS115 (his4) strain (Invitrogen).

\section{Construction of Pichia pastoris recombinant strains expressing NpaBGS}

Ten $\mu \mathrm{g}$ of the pPICZA-NpaBGS DNA was linearized with BglII and transformed into the yeast P. pastoris GS115 strain by electroporation. A $200 \mu \mathrm{L}$ aliquot was spread on YPD plates containing $100 \mu \mathrm{g} / \mathrm{mL}$ zeocin and incubated at $30^{\circ} \mathrm{C}$. Another aliquot of electroporated cells was spread onto YPD plates containing $1,000 \mu \mathrm{g} / \mathrm{mL}$ zeocin to screen for colonies with high copy insertion. One transformant confirmed for the $\mathrm{Mut}^{+}$phenotype was scored and grown in $10 \mathrm{~mL}$ of BMGY medium. The yeast colony was cultured at $30^{\circ} \mathrm{C}$ with orbital shaking at $250 \mathrm{rpm}$ for about $20 \mathrm{~h}$ until the density reached $\mathrm{OD}_{600}$ of 5.0. The yeast culture was harvested by centrifugation at 2,000 $\mathrm{g} g$ for $5 \mathrm{~min}$ at room temperature. To induce expression via the AOX1 promoter, the pellet was resuspended in $50 \mathrm{~mL}$ of BMMY medium and grown at $30^{\circ} \mathrm{C}$ with $250 \mathrm{rpm}$ shaking for 5 days, during which methanol was added to the concentration of $0.5 \%$ at 24-hr intervals to maintain induction, and the activity of the culture was examined simultaneously. In order to increase the level of induction, various concentrations of methanol (from 0.5 to $3 \%$ ) were also tested.

\section{Purification of recombinant NpaBGS}

The yeast broth $(4 \mathrm{~L})$ was percolated through filter paper (Toyo Roshi Kaisha, Japan) and concentrated with a stirred ultrafiltration cell (model 8400; Millipore Corp.) equipped with a PM 10 membrane (Millipore Corp., USA) under the nitrogen pressure of $4.0 \mathrm{~kg} . \mathrm{f} / \mathrm{cm}^{2}$ and dialyzed against
$20 \mathrm{mM}$ sodium acetate buffer ( $\mathrm{pH}$ 5.0). The extracted enzyme was condensated by precipitation at increasing concentrations of ammonium sulfate (0-30\%, 30-50\%, and $50-70 \%)$ at $5^{\circ} \mathrm{C}$. The fraction contained better activity and amount of enzyme was found at 50-70 \% ammonium sulfate precipitation. The resulting precipitates were collected by cold centrifugation, dissolved in distilled water and dialyzed $\left(0.1 \mathrm{M}\right.$ phosphate buffer, $\left.\mathrm{pH} 6.0,48 \mathrm{~h}, 5^{\circ} \mathrm{C}\right)$ to remove excessive salt. The protein $(30 \mathrm{~mL})$ was then loaded onto a Toyopearl DEAE-650 S (Tosoh, Japan) column $(2.0 \times 20 \mathrm{~cm})$ and eluted with a step gradient of $0,200,300$, 400 , and $500 \mathrm{mM}$ of $\mathrm{NaCl}$ in a volume of $1,000 \mathrm{~mL}$. The fractions showing cellulolytic activity were pooled and concentrated by ultrafiltration, then dialyzed against $50 \mathrm{mM}$ sodium acetate $(\mathrm{pH} 5.0)$ containing $0.15 \mathrm{M} \mathrm{NaCl}$. The dialyzed sample $(4 \mathrm{~mL})$ was applied to a Sephacryl 300-S HR (GE Healthcare Bio-Sciences AB) column $(1.6 \times 60 \mathrm{~cm})$ and eluted with the same buffer at a flow rate of $0.5 \mathrm{ml} / \mathrm{min}$. The active fractions were concentrated by ultrafiltration and dialyzed against $20 \mathrm{mM}$ Tris- $\mathrm{HCl}$ buffer $(\mathrm{pH} 8.0)$ containing $1.5 \mathrm{M}\left(\mathrm{NH}_{4}\right)_{2} \mathrm{SO}_{4}$. The dialyzed enzyme solution $(2.0 \mathrm{~mL})$ was then loaded onto a Resource PHE (Amersham Biosciences, USA) column $(1.0 \times 1.0 \mathrm{~mL})$ equilibrated with the same buffer containing $1.5 \mathrm{M}\left(\mathrm{NH}_{4}\right)$ ${ }_{2} \mathrm{SO}_{4}$. The active fractions were eluted with a decreasing linear gradient from 1.5 to $0 \mathrm{M}$ of $\left(\mathrm{NH}_{4}\right)_{2} \mathrm{SO}_{4}$ in the buffer at a flow rate of $1.0 \mathrm{~mL} / \mathrm{min}$. The fractions containing the $\beta$-glucosidase activity were further concentrated with an Ultrafree- 0.5 centrifugal filter (Millipore Corp., USA), and the purity was checked by sodium dodecyl sulfate-polyacrylamide gel electrophoresis (SDS-PAGE). Protein samples were electrophoresed on $12 \%$ (w/v) SDS-PAGE gels and visualized by staining with Coomassie Brilliant Blue R250 [42]. The molecular weight markers were obtained from Fermentas (USA). Protein concentration was determined using a protein assay kit (Bio-Rad Laboratories Inc., Hercules, California, USA). Native PAGE electrophoresis was carried out similarly by exclusion of SDS from all solutions. Zymogram after native PAGE was performed as described by Feng et al. [43] and Duan et al. [18].

\section{Characterization of recombinant NpaBGS enzymatic properties}

After optimizing the culture conditions of the P. pastoris recombinant strain for producing NpaBGS, the $\beta$-glucosidase activity in the culture medium supernatant was measured. $\beta$-glucosidase activity was assayed by adding $10 \mu \mathrm{l}$ of culture supernatant to $90 \mu \mathrm{L}$ of $2 \%$ (w v) cellobiose (low viscosity), and the amount of glucose assay was carried out according to the manual of Glucose (HK) assay kit (SigmaAldrich, USA). One unit (U) of $\beta$-glucosidase activity was defined as the amount of $1 \mu$ mole glucose released per minute at $\mathrm{pH} 7.0$ under the assay conditions described below. Furthermore, other natural substrates, such as 
amygdalin, arbutin, larminarin, phenyl- $\beta$-D-glucoside, and $\beta$-gentiobiose, and substrates, such as 4-methylumbel-liferyl- $\beta$-D-cellobioside (MUC), 4-mehtylumbelliferyl- $\beta$-D-galactopyronoside (MUG) and 4-methylumbelliferyl- $\beta$-D- glucopyranoside (MUD) were also assayed at in the same condition.

The temperature profile and the optimum temperature of NpaBGS were determined by the activity on cellobiose at $30,40,50$, and $60^{\circ} \mathrm{C}$. The optimum $\mathrm{pH}$ was determined using $100 \mathrm{mM}$ buffers: sodium citrate (pH 2.0 and 3.0), sodium acetate (from pH 4.0 to $\mathrm{pH} 6.0$ ) and Tris- $\mathrm{HCl}$ (form $\mathrm{pH} 6$ to $\mathrm{pH}$ 9). The thermostability of NpaBGS and the commercial enzyme Novo 188 (Novozymes, Bagsvaerd, Denmark) were compared by incubation at $40^{\circ} \mathrm{C}$ in $100 \mathrm{mM}$ in Tris- $\mathrm{HCl}$ buffer (pH 6.0) during a time course and then measured their $\beta$-glucosidase activity against cellobiose.

To evaluate the effect on the $\beta$-glucosidase activity of metal cations, such as $\mathrm{Al}^{3+}, \mathrm{Ca}^{2+}, \mathrm{Cu}^{2+}, \mathrm{Fe}^{3+}, \mathrm{Mg}^{2+}, \mathrm{Mn}^{2+}$, and $\mathrm{Zn}^{2+}$, and reducing agents, such as DTT, and $\beta$-mercaptoenthanol, these elements were added separately to the standard assay in $100 \mathrm{mM}$ Tris- $\mathrm{HCl}$ buffer, $\mathrm{pH}$ 6.0, to a final concentration of 1 and $10 \mathrm{mM}$, respectively.

\section{Efficiency of $\beta$-glucosidase in SSF application}

S. cerevisiae BY4741 and Kluyveromyces marxianus KY3 [40] were used in SSF experiments to study the effect of different culture temperatures. Both yeasts could grow at $30^{\circ} \mathrm{C}$ on the solid YPAD medium (1\% yeast extract, $2 \%$ peptone, $24 \mathrm{mg} / \mathrm{L}$ adenine hemisulfate, $2 \%$ glucose, and $2 \%$ agar), while separate cultures of $K$. marxianus KY3 was also examined at $37^{\circ} \mathrm{C}$ and $40^{\circ} \mathrm{C}$ for its thermotolerance. First, the two microbes were pre-cultured overnight in YPAD medium and inoculated to initial O.D. $600 \mathrm{~nm} 0.1 \mathrm{in}$ $10 \mathrm{ml}$ of fresh YPA medium containing either $2 \%$ glucose or $2 \%$ cellobiose under an aerobic condition. The experimental groups were the YPA medium with $2 \%$ cellobiose and supplemented with an equal unit ( 2 units) of NpaBGS or Novo $188 \beta$-glucosidase in the culture. The growth curve, glucose generation and ethanol production of these cultures were determined at $0,12,16,20$, and 24 hrs. The cell density was measured at $600 \mathrm{~nm}$ by spectrophotometer (Ultrospec 2100 pro, GE Healthcare Bio-Sciences AB). In a parallel experiment, the SSF experiment was conducted using $2 \%$ dry napiergrass as the sole carbon source, and adding $2 \mathrm{ml}$ of commercial Celluclast $1.5 \mathrm{~L}$ in a $50 \mathrm{ml}$ yeast culture at $40^{\circ} \mathrm{C}$. In addition, $K$. marxianus $\mathrm{KY} 3$ and KY3NpaBGS, in which KY3 was transformed with the NpaBGS gene via a commercial expression system (K. lactis Protein Expression Kit, New England Biolabs) [40], were used in the SSF experiment. Glucose and ethanol assays were performed using Glucose (HK) assay kits and Ethanol Enzymatic BioAnalysis kits (Roche Molecular Biochemicals, Germany) following manufacturer's procedures.

\section{Additional files}

Additional file 1: Nucleotide and deduced amino acid sequences of the NpaBGS cDNA. Amino acids are represented below the nucleotide sequence. The signal peptide is labeled with asterisks. The potential sites of $\mathrm{N}$-glycosylation and activity site are shown in gothic font. The predicted domains of $\mathrm{GH} 3$ at the $\mathrm{N}$ and $\mathrm{C}$ terminal are underlined.

Additional file 2: NpaBGS enzyme activity on CMC.

\section{Abbreviations}

CMC: Carboxymethyl cellulose; DTT: Dithiothreitol; MUC: 4-methylumbelliferyl- $\beta$-D-cellobioside; MUD: 4-methylumbel-liferyl- $\beta$-D-glucopyranoside; MUG: 4-mehtylumbelliferyl- $\beta-D$-galactopyronoside; SSF: Simultaneous saccharification and fermentation.

\section{Competing interests}

The authors declare that they have no competing interests.

\section{Acknowledgements}

We thank Dr. Huang-Mo Sung and Dr. Andrew H.-J. Wang for advice on experiments and Mr. Shang-Lin Tsai, Mr. Bing-Shi Tsai and Dr. Wen-Yih Jeng for their assistance. This research was supported by funding from National Science Council (NSC 96-3114-P-001-004-Y and NSC 97-3114-P-001-001), Taiwan.

\section{Author details}

${ }^{1}$ Biodiversity Research Center, Academia Sinica, Taipei 115, Taiwan.

${ }^{2}$ Department of Biological Science \& Technology, National Pingtung University of Science \& Technology, Neipu Hsiang, Pingtung 91201, Taiwan. ${ }^{3}$ Genomics Research Center, Academia Sinica, Taipei 115, Taiwan. ${ }^{4}$ Molecular and Biological Agricultural Sciences Program, Taiwan International Graduate Program, National Chung-Hsing University - Academia Sinica, Taipei 115, Taiwan. ${ }^{5}$ Graduate Institute of Biotechnology, National Chung-Hsing University, Taichung 402, Taiwan. ${ }^{6}$ Agricultural Biotechnology Research Center, Academia Sinica, Taipei 115, Taiwan. ${ }^{7}$ Program in Microbial Genomics, National Chung-Hsing University, Taichung 402, Taiwan. ${ }^{8}$ Biotechnology Center, National Chung-Hsing University, Taichung 402, Taiwan. ${ }^{9}$ Department of Ecology and Evolution, University of Chicago, Chicago IL 60637, USA.

\section{Authors' contributions}

$H-L C, Y-C, C, J-J C$ and $M-Y J L$ designed experiments. $H-L C, M-Y J L, J-J C$, H-M K, S-K R, T-Y W, K-Y H, H-Y C, and W-T L carried out the experiments, analyzed the data and drafted the manuscript. H-L C, J-J C and T-Y W drafted the manuscript. M-C S and W-H L supervised the study and revised the manuscript. All authors read and approved the final manuscript.

\section{Received: 21 November 2011 Accepted: 19 April 2012}

Published: 19 April 2012

\section{References}

1. Lynd LR, Weimer PJ, van ZyI WH, Pretorius IS: Microbial cellulose utilization: fundamentals and biotechnology. Microbiol Mol Biol Rev 2002, 66(3):506-577.

2. Theodorou MK, Longland AC, Dhanoa MS, Lowe SE, Trinci APJ: Growth of Neocallimastix sp. strain R1: on Italian ryegrass hay: removal of neutral sugars from plant cell walls. App/ Environ Microbiol 1989, 55(6):1363-1367.

3. Da-Silva R, Gomes E, Franco CML: Pectinases, hemicelulase e cellulases substrate, production application no processamento de alimentos. Bol SBCTA 1997, 31:249-250.

4. Wubah DA: Anaerobic zoosporic fungi associated with animals. In Biodiversity of Fungi: Inventory and Monotoring Methods. In Edited by Mueller GM, Bills GF, Foster MS. Burlington, MA: Elsevier Academic Press; 2004:501-510.

5. Woodward J, Lima M, Lee NE: The role of cellulase concentration in determining the degree of synergism in the hydrolysis of microcrystalline cellulose. Biochem J 1982, 255(3):895-899.

6. Leclerc MAA, Ratomahenina R, Galzy P: Yeast $\beta$-glucosidases. Biotechnol Genet Eng Rev 1987, 5:269-295.

7. Bhat MK, Bhat S: Cellulose degrading enzymes and their potential industrial applications. Biotechnol Adv 1997, 15(3-4):583-620.

8. Shinoyama HTV, Ando A, Fujii T, Sasaki M, Doi Y, Yasui T: Enzymatic synthesis of useful alkyl- $\beta$-glucosides. Agri Biol Chem 1991, 55:1679-1681. 
9. Saha BC, Freer SN, Bothast RJ: Production, purification, and properties of a thermostable beta-glucosidase from a color variant strain of Aureobasidium pullulans. Appl Environ Microbiol 1994, 60(10):3774-3780.

10. Henrissat B: A classification of glycosyl hydrolases based on amino acid sequence similarities. Biochem J 1991, 280(Pt 2):309-316.

11. Henrissat B: Glycosidase families. Biochem Soc Trans 1998, 26(2):153-156.

12. Dan S, Marton I, Dekel M, Bravdo BA, He S, Withers SG, Shoseyov O: Cloning, expression, characterization, and nucleophile identification of family 3 , Aspergillus niger $\beta$-glucosidase. J Biol Chem 2000, 275(7):4973-4980.

13. Claeyssens M, Van Tilbeurgh H, Tomme P, Wood TM, McCrae I: Fungal cellulase systems. Comparison of the specificities of the cellobiohydrolases isolated from Penicillium pinophilum and Trichoderma reesei. Biochem J 1989, 261(3):819-826.

14. Eriksson KEL, Blanchette RA, Ander P: Microbial and enzymatic degradation of wood and wood components. Berlin/Heidelberg, Germany: Springer Verlag; 1990.

15. Uzcategui E, Johansson G, Ek B, Pettersson G: The 1,4- $\beta$-D-glucan glucanohydrolases from Phanerochaete chrysosporium. Reassessment of their significance in cellulose degradation mechanisms. J Biotechnol 1991, 21(1-2):143-159.

16. Trinci APJ, Davies DR, Gull K, Lawrence MI, Nielsen BB, Rickers A, Theodorou MK: Anaerobic fungi in herbivorous animals. Mycol Res 1994, 96(2):129-152.

17. Selinger LB, Forsberg CW, Cheng KJ: The rumen: a unique source of enzymes for enhancing livestock production. Anaerobe 1996, 2:263-284.

18. Duan CJ, Xian L, Zhao GC, Feng Y, Pang H, Bai XL, Tang JL, Ma QS, Feng JX: Isolation and partial characterization of novel genes encoding acidic cellulases from metagenomes of buffalo rumens. J Appl Microbiol 2009, 107(1):245-526.

19. Wang TY, Chen HL, Lu MY, Chen YC, Sung HM, Mao CT, Cho HY, Ke HM, Hwa TY, Ruan SK, Hung KY, Chen CK, Li JY, Wu YC, Chen YH, Chou SP, Tsai YW, Chu TC, Shih CC, Li WH, Shih MC: Functional characterization of cellulases identified from the cow rumen fungus Neocallimastix patriciarum W5 by transcriptomic and secretomic analyses. Biotechnol Biofuels 2011, 4:24.

20. Henrissat B, Callebaut I, Fabrega S, Lehn P, Mornon JP, Davies G: Conserved catalytic machinery and the prediction of a common fold for several families of glycosyl hydrolases. Proc Natl Acad Sci USA 1995, 92(15):7090-7094.

21. Makoto M, Isao O, Sakuzo F, Ichiro Y: Nucleotide sequences of Saccharomycopsis fibuligera genes for extracellular $\beta$-glucosidases as expressed in Saccharomyces cerevisiae. Appl Microbiol Biotechnol 1988, 54 (12):3147-3155.

22. Wong WK, Ali A, Chan WK, Ho V, Lee NT: The cloning, expression and characterization of a cellobiase gene encoding a secretory enzyme from Cellulomonas biazotea. Gene 1998, 207:79-86.

23. Jeya M, Joo AR, Lee KM, Tiwari MK, Lee KM, Kim SH, Lee JK: Characterization of beta-glucosidase from a strain of Penicillium purpurogenum KJS506. App/ Microbiol Biotechnol 2010, 86(5):1473-1484.

24. Harnpicharnchai P, Champreda V, Sornlake W, Eurwilaichitr L: A thermotolerant $\beta$-glucosidase isolated from an endophytic fungi, Periconia sp., with a possible use for biomass conversion to sugars. Protein Express Purif 2009, 67(2):61-69.

25. Kim CH, Kim DS: Purification and specificity of a specific endo-beta-1,4- $\beta$ -glucanase (Avicelase-II) resembling exo-cellobio-hydrolase from Bacillus circulans. Enzyme Microbiol Technol 1995, 17(3):248-254.

26. Meinke A, Damude HG, Tomme P, Kwan E, Kilburn DG, Miller RC Jr, Warren RA, Gilkes NR: Enhancement of the endo-b-1,4-glucanase activity of an exocellobiohydrolase by deletion of a surface loop. J Biol Chem 1995, 270 (9):4383-4386.

27. Tomme P, Warren RAJ, Gilkes NR: Cellulose hydrolysis by bacteria and fungi. Adv Microbiol Physiol 1995, 37:1-81.

28. Rubini MR, Dillon AJP, Kyaw CM, Faria FP, Poças-Fonseca MJ, Silva-Pereira I: Cloning, characterization and heterologous expression of the first Penicillium echinulatum cellulase gene. J Appl Microbiol 2009, 108(4): 1187-1198.

29. Yeoh HH, Tan TK, Koh SK: Kinetic propeties of $\beta$-glucosidases from Aspergillus ornatus. Appl Microbiol Biotechnol 1986, 25:25-28.

30. Toonkool P, Metheenukul P, Sujiwattanarat P, Paiboon P, Tongtubtim N, Ketudat-Cairns M, Ketudat-Cairns J, Svasti J: Expression and purification of dalcochinase, a $\beta$-glucosidase from Dalbergia cochinchinensis Pierre, in yeast and bacterial hosts. Protein Expr Purif 2006, 48(2):195-204.
31. Shipkowski S, Brenchley JE: Characterization of an unusual cold-active $\beta$ glucosidase belonging to family 3 of the glycoside hydrolases from the psychrophilic isolate Paenibacillus sp. Strain C7. Appl Environ Microbiol 2005, 71(8):4225-4232.

32. Chauvaux S, Beguin P, Aubert JP, Bhat KM, Gow LA, Wood TM, Bairoch A: Calcium-binding affinity and calcium-enhanced activity of Clostridium thermocellum endoglucanase D. Biochem J 1990, 265(1):261-655.

33. Wallecha A, Mishra S: Purification and characterization of two $\beta$ glucosidases from a thermo-tolerant yeast Pichia etchellsii. Biochim Biophys Acta 2003, 1649(1):74-84.

34. Rouvinen J, Bergfors T, Teeri T, Knowles JK, Jones TA: Three-dimensional structure of cellobiohydrolase II from Trichoderma reesei. Science 1990, 249(4967):380-386.

35. Copa-Patino JL, Broda P: A Phanerochaete chrysosporium $\beta$-D-glucosidase/ $\beta$-Dxylosidase with specificity for $(1 \rightarrow 3)$ - $\beta$-D-glucan linkages. Carbohydrate Res 1994, 253:265-275.

36. Ohmiya Y, Takeda T, Nakamura S, Sakai F, Hayashi T: Purification and properties of a wall-bound endo-1,4-b-glucanase from suspensioncultured poplar cells. Plant Cell Physiol 1995, 36:607-614.

37. Hsieh MC, Graham TL: Partial purification and characterization of a soybean $\beta$-glucosidase with high specific activity towards isoflavone conjugates. Phytochemistry 2001, 58(7):995-1005.

38. Champreda V, Kanokratana P, Sriprang R, Tanapongpipat S, Eurwilaichitr L: Purification, biochemical characterization, and gene cloning of a new extracellular thermotolerant and glucose tolerant maltooligosaccharideforming alpha-amylase from an endophytic ascomycete Fusicoccum $\mathrm{sp}$. BCC4124. Biosci Biotechnol Biochem 2007, 71(8):2010-2020.

39. Gifford JL, Walsh MP, Vogel HJ: Structures and metal-ion-binding properties of the $\mathrm{Ca}^{2+}$-binding helix-loop-helix EF-hand motifs. Biochem J 2007, 405:199-221.

40. Ho CY, Chang JJ, Huang YR, Wu YC, Li WH, Shih MC, Huang CC: Isolation and characterization of a flavor production kefir yeast Kluyveromyces marxianus KY3: a potential strain for developing co-cultural consolidated bioprocess. Biomass Bioenergy 2011, revised.

41. Lynd LR, van Zyl WH, McBride JE, Laser M: Consolidated bioprocessing of cellulosic biomass: an update. Curr Opin Biotechnol 2005, 16(5):577-583.

42. Laemmli UK: Cleavage of structural proteins during the assembly of the head of bacteriophage T4. Nature 1970, 227(5259):680-685.

43. Feng Y, Duan CJ, Pang H, Mo XC, Wu CF, Yu Y, Hu YL, Wei J, Tang JL, Feng $J X:$ Cloning and identification of novel cellulase genes from uncultured microorganisms in rabbit cecum and characterization of the expressed cellulases. Appl Microbiol Biotechnol 2007, 75(2):319-328.

doi:10.1186/1754-6834-5-24

Cite this article as: Chen et al: A highly efficient $\beta$-glucosidase from the buffalo rumen fungus Neocallimastix patriciarum W5. Biotechnology for Biofuels 2012, 5:24.

\section{Submit your next manuscript to BioMed Central and take full advantage of:}

- Convenient online submission

- Thorough peer review

- No space constraints or color figure charges

- Immediate publication on acceptance

- Inclusion in PubMed, CAS, Scopus and Google Scholar

- Research which is freely available for redistribution 